\title{
ANALISIS TRIWULANAN: Perkembangan Moneter, Perbankan dan Sistem Pembayaran, Triwulan III - 2009
}

\author{
Tim Penulis Laporan Triwulanan, Bank Indonesia
}

Perkembangan perekonomian global yang terus menunjukkan pemulihan telah berdampak pada membaiknya ekonomi domestik. Ekonomi Indonesia berpotensi tumbuh lebih baik dari perkiraan semula, baik untuk tahun 2009 maupun tahun 2010. Di tahun 2009, ekonomi Indonesia diperkirakan tumbuh sebesar 4,0-4,5\% atau lebih tinggi dari perkiraan sebelumnya sebesar 3,5-4,0\%. Sementara itu, untuk tahun 2010, pertumbuhan ekonomi diperkirakan mencapai 5,0-5,5\%.

Proses pemulihan yang terjadi pada perekonomian global terus menunjukkan indikasi yang semakin menguat dan merata di berbagai negara. Perbaikan yang paling tampak adalah di negara-negara emerging market Asia, terutama China. Sementara di negara maju, kontraksi ekonomi mulai melambat. Dari berbagai indikator makro ekonomi global, terlihat optimisme pemulihan ekonomi global semakin menguat. Perkembangan penjualan eceran, utilisasi kapasitas, dan indeks produksi, mulai meningkat baik di negara maju maupun negara emerging markets. Meski menunjukkan perbaikan, beberapa faktor risiko masih membayangi pemulihan ekonomi. Risiko tingkat pengangguran yang masih tinggi di negara-negara maju menjadi kendala bagi perbaikan kinerja perekonomian global lebih lanjut.

Pemulihan yang terjadi pada perekonomian dunia juga terefleksi pada perkembangan yang membaik di pasar keuangan global. Sepanjang triwulan III-2009, tingkat risiko di negara maju dan berkembang mulai membaik. Hal itu tercermin pada perkembangan indikator risiko atau Currency Default Swap (CDS) yang terus menurun. Pasar saham global pada triwulan III2009 masih berada dalam tren yang meningkat meski sempat mengalami koreksi harga. Di sektor riil, optimisme terhadap pemulihan ekonomi dan tren pelemahan dolar AS mendorong kenaikan harga komoditas internasional. Namun, kenaikan harga tersebut belum memberikan tekanan yang signifikan terhadap perkembangan harga secara keseluruhan. Inflasi negara maju dan emerging markets masih relatif rendah, bahkan beberapa negara masih mengalami deflasi sejalan dengan kinerja konsumsi yang masih sepenuhnya belum pulih. 
Di sisi domestik, perekonomian Indonesia menunjukkan perkembangan yang lebih baik seiring dengan terus membaiknya perekonomian global. Pertumbuhan PDB pada triwulan III2009 diperkirakan mencapai 4,2\%, lebih tinggi dibandingkan perkiraan sebelumnya sebesar 3,9\%. Dari sisi permintaan, kinerja konsumsi meningkat ditopang oleh pendapatan ekspor yang meningkat, keyakinan konsumen yang lebih kuat, serta faktor musiman menjelang hari raya Idhul Fitri. Kinerja investasi diperkirakan sedikit membaik, meski masih tumbuh rendah. Dari sisi eksternal, pertumbuhan ekspor diperkirakan lebih tinggi sejalan dengan ekonomi negara mitra dagang yang semakin membaik, serta harga komoditas global yang meningkat. Sementara, pertumbuhan impor diperkirakan masih minimal. Di sisi penawaran, sektor industri pengolahan dan perdagangan, hotel dan restoran, tumbuh membaik pada triwulan III-2009 seiring dengan perayaan Idhul Fitri.

Pertumbuhan ekonomi Indonesia yang membaik tersebut juga terkonfirmasi oleh hasil asesmen perekonomian daerah yang dilakukan Bank Indonesia. Secara umum, perekonomian daerah masih menunjukkan kuatnya konsumsi dan ekspor sejalan meningkatnya permintaan produk primer dari China, India dan Korea Selatan, serta mulai meningkatnya kegiatan investasi di seluruh wilayah. Peningkatan ekspor dari wilayah Sumatera dan Kali-Sulampua (KalimantanSulawesi-Maluku-Papua) terutama berasal dari komoditas karet, nikel, batubara dan CPO. Sumber pertumbuhan dari wilayah Jakarta berupa komoditas hasil industri pengolahan. Sementara dari sisi penawaran, pertumbuhan ekonomi wilayah Jakarta terutama ditunjang oleh membaiknya kinerja sektor industri, sektor perdagangan, hotel dan restoran, serta sektor keuangan. Di wilayah Jabalnustra (Jawa-Bali-Nusa Tenggara) pertumbuhan ekonomi didukung oleh sektor pertanian tanaman bahan makanan dan sektor perdagangan, serta wilayah Sumatra dan Kali-Sulampua dipicu oleh sektor pertambangan dan subsektor perkebunan. Meningkatnya pertumbuhan ekonomi daerah juga didukung oleh realisasi belanja modal pemerintah daerah (APBD) yang umumnya mulai meningkat di triwulan III-2009. Sementara itu, terjadinya gempa di wilayah Sumatera Barat diperkirakan akan mempengaruhi pertumbuhan ekonomi di wilayah Sumatera Barat, Sektor unggulan yang selama ini membentuk ekonomi di Sumatera Barat, seperti sektor pertanian, perdagangan, hotel, dan restoran, serta pengangkutan dan komunikasi, diperkirakan terpukul akibat gempa. Namun apabila dilihat secara nasional, pangsa perekonomian Sumatera Barat terhadap pertumbuhan nasional relatif masih kecil, yaitu sebesar $1,7 \%$ dari pertumbuhan ekonomi nasional.

Di sisi harga, tren penurunan inflasi selama triwulan III-2009 terus menurun mencapai 2,83\% (yoy). Rendahnya tekanan inflasi selama triwulan III-2009 terkait dengan ekspektasi inflasi yang membaik, nilai tukar rupiah yang menguat, dan perkembangan harga komoditas global yang masih rendah. Sementara, tekanan dari sisi permintaan masih minimal meski 
terindikasi sudah mulai meningkat. Dari faktor non-fundamental, selama triwulan III-2009, kebijakan Pemerintah di bidang harga masih minimal serta pasokan bahan pangan yang melimpah turut mengurangi tekanan terhadap harga. Kenaikan harga ruas tol pada 28 September 2009 diperkirakan memberi dampak minimal terhadap inflasi, sebesar 0,05\% pada pembentukan inflasi di tahun 2009.

Membaiknya perekonomian global, terutama negara mitra dagang, berpotensi memberi dampak positif pada kinerja Neraca Pembayaran Indonesia triwulan III-2009. Pemulihan ekonomi global tersebut, terutama ekonomi negara mitra dagang, serta harga komoditas global yang cenderung meningkat, berpotensi mendorong kinerja ekspor lebih tingg. Sementara, impor diperkirakan masih rendah terkait dengan kebutuhan investasi yang masih lemah. Neraca transaksi berjalan triwulan III-2009 berpotensi mencatat surplus. Sementara di sisi transaksi modal dan finansial (TMF), meski sempat mengalami penyesuaian portofolio asing pada Agustus 2009, arus masuk dana asing dan investasi dalam bentuk portofolio masih mencatat surplus.

Sementara itu, peningkatan sovereign credit rating Indonesia dari Ba3 menjadi Ba2 oleh Moodys diperkirakan berdampak positif terhadap aliran modal masuk dan ongkos dalam pembiayaan. Selain itu, sebagai bagian dari langkah kebijakan global yang terkoordinir, Indonesia seperti negara anggota IMF lainnya mendapatkan alokasi SDR yaitu sebesar SDR 1,74 miliar atau setara dengan USD 2,7 miliar. Dengan perkembangan tersebut, cadangan devisa di akhir September 2009 mencapai USD 62,3 miliar, yang mencukupi untuk 6,2 bulan impor dan pembayaran ULN pemerintah.

Membaiknya Neraca Pembayaran Indonesia dan sentimen positif di pasar keuangan global turut mendorong kestabilan nilai tukar rupiah. Meski sempat mengalami tekanan pada akhir Agustus 2009, nilai tukar bergerak menguat dengan volatilitas yang menurun. Penguatan rupiah ini didukung oleh fundamental ekonomi domestik yang masih kuat seperti tercermin pada neraca transaksi berjalan yang mencatat surplus, imbal hasil yang menarik, serta persepsi risiko yang membaik sehingga menjadi daya tarik bagi investor asing. Selain itu, sentimen positif ekonomi global turut mendukung derasnya arus masuk modal asing ke Indonesia. Rupiah juga relatif masih kompetitif dibandingkan negara kawasan. Selama triwulan III-2009, rata-rata rupiah menguat 5,55\% ke level Rp 9.973 per dolar AS dengan volatilitas yang menurun.

Di sektor keuangan, berbagai perkembangan di atas telah memberikan dampak positif pada kondisi sektor keuangan domestik. Secara umum, kinerja pasar keuangan meningkat dan transmisi kebijakan moneter terus membaik. Di pasar saham, perkembangan bursa efek selama triwulan III-2009 ditandai oleh peningkatan indeks harga. Fundamental domestik yang membaik serta harga komoditas global yang meningkat merupakan faktor yang mendorong 
pembelian saham baik oleh investor asing maupun domestik yang signifikan. Di pasar obligasi, yield SUN menurun sejalan dengan perkembangan BI Rate yang lebih rendah dan minat investor asing terhadap SUN yang meningkat. Namun demikian, yield SUN untuk tenor jangka panjang (di atas 15 tahun) masih cenderung tinggi terkait dengan persepsi risiko yang masih tinggi.

Di sektor perbankan, kondisi perbankan nasional relatif stabil dan respons perbankan terhadap sinyal kebijakan moneter mulai membaik. Secara mikro, kondisi perbankan nasional tetap stabil, yang diindikasikan oleh masih terjaganya rasio kecukupan modal (Capital Adequacy Ratio/CAR) per Agustus 2009 yang cukup tinggi mencapai level 17,0\%. Sementara itu, rasio gross Non Performing Loan (NPL) tetap terkendali di bawah 5\% dengan rasio net di bawah $2 \%$. Likuiditas perbankan cukup likuid tercermin dari simpanan perbankan pada instrumen moneter (SBI dan FASBI) yang meningkat, volume transaksi di pasar uang antar bank yang lebih besar, dan suku bunga Pasar Uang Antar Bank (PUAB) overnight yang menurun dan cenderung lebih rendah dari BI rate. Sementara itu, respons suku bunga perbankan terhadap kebijakan moneter masih membaik, terutama pada suku bunga simpanan. Sampai dengan pertengahan triwulan III-2009, rata-rata suku bunga kredit menurun sebesar 18 bps atau lebih besar dari periode yang sama di triwulan sebelumnya. Terkait dengan hal tersebut, penyaluran kredit perbankan dari Januari sampai dengan Agustus 2009 masih mencatat 46,7 triliun sebesar $3,5 \%(y t d)$.

Ke depan, prospek perekonomian Indonesia di tahun 2009 dan 2010 berpotensi tumbuh lebih baik dari perkiraan semula. Hal tersebut terutama didukung oleh pertumbuhan konsumsi swasta yang masih kuat, kinerja ekspor yang lebih tinggi dari perkiraan semula, serta stimulus Pemerintah. Kinerja konsumsi swasta yang masih kuat didukung oleh tingkat keyakinan konsumen yang tinggi sejalan dengan inflasi dan suku bunga yang rendah serta dampak dari pendapatan ekspor yang meningkat. Sementara itu, perbaikan kinerja ekspor dipengaruhi oleh proses perbaikan ekonomi global yang semakin kuat, serta peningkatan harga komoditas baik non migas maupun migas. investasi diperkirakan masih tumbuh terbatas terkait dengan tingkat utilisasi kapasitas produksi yang masih rendah. Stimulus fiskal Pemerintah juga mampu menopang kinerja ekonomi domestik tercermin pada pertumbuhan konsumsi dan investasi Pemerintah yang cukup tinggi. Dari sisi penawaran, pertumbuhan berbagai sektor diperkirakan mulai berada pada tahapan yang meningkat. Hal ini sejalan dengan permintaan domestik dan eksternal terhadap sektor-sektor tradable yang meningkat. Dengan perkembangan tersebut, perekonomian Indonesia di tahun 2009 diperkirakan tumbuh 4,0-4,5\%, lebih baik dari perkiraan semula 3,5-4,0\%. Sementara itu, untuk tahun 2010, Bank Indonesia memperkirakan pertumbuhan ekonomi mencapai kisaran 5,0-5,5\%. Beberapa faktor risiko perlu dicermati antara lain bersumber pada masih adanya ketidakpastian proses pemulihan perdagangan dunia 
mengingat proses pemulihan di negara maju yang didukung stimulus fiskal lebih berorientasi pada permintaan domestik, masih tingginya angka pengangguran di negara maju, dan masih terdapatnya kecenderungan proteksionisme di beberapa negara pasca krisis global. Di samping itu, risiko meningkatnya harga minyak dunia yang didorong oleh kegiatan spekulasi perlu terus dicermati.

Di sisi Neraca Pembayaran, kinerja Neraca Pembayaran Indonesia untuk tahun 2009 dan 2010 diperkirakan mencatat surplus yang semakin membaik. Kegiatan ekspor diperkirakan membaik didukung oleh proses pemulihan ekonomi dunia serta kenaikan harga komoditas. Di sisi domestik, impor diperkirakan masih tumbuh terbatas mengingat kegiatan investasi yang masih tumbuh rendah. Sementara untuk tahun 2010, neraca transaksi berjalan diperkirakan masih akan mencatat surplus. Sementara itu, kinerja transaksi modal dan finansial ditopang oleh kondisi domestik dan eksternal yang lebih kondusif dibandingkan sebelumnya. Kondisi fundamental domestik yang terjaga, persepsi risiko yang membaik, serta minat investor terhadap aset domestik yang masih kuat diperkirakan mampu mendorong arus masuk modal asing ke Indonesia, baik dalam bentuk investasi portofolio maupun penanaman modal asing.

Di sisi prospek inflasi, tren penurunan inflasi di tahun 2009 diperkirakan masih berlanjut, namun memiliki potensi untuk kembali ke pola normalnya pada tahun 2010. Selama tahun 2009, inflasi IHK diperkirakan akan mencapai kisaran sasaran inflasi 4,5 $\pm 1 \%$. Untuk tahun 2010, inflasi IHK diperkirakan kembali ke pola normalnya dalam kisaran $5 \pm 1 \%$ terkait dengan mulai meningkatnya kegiatan ekonomi dalam negeri, meningkatnya imported inflation sehubungan dengan kenaikan harga komoditas, serta ekspektasi inflasi. Dari sisi nonfundamental, kenaikan tekanan inflasi diprakirakan bersumber dari kenaikan beberapa administered pricesyang bersifat non-strategis. Sementara itu, inflasi volatile food diprakirakan cukup rendah sejalan dengan pasokan dan distribusi bahan pangan dan energi yang cukup terjaga.

Dengan mempertimbangkan perkembangan-perkembangan tersebut di atas, Rapat Dewan Gubernur Bank Indonesia pada 5 Oktober 2009 memutuskan untuk mempertahankan BI Rate pada level 6,5\%. Keputusan mempertahankan BI Rate tersebut diambil setelah Rapat Dewan Gubernur menyimpulkan bahwa tingkat suku bunga BI rate sebesar 6,50\% masih konsisten dengan pencapaian sasaran inflasi pada tahun 2010 sebesar $5 \% \pm 1 \%$. Stance kebijakan saat ini juga dipandang masih kondusif bagi proses pemulihan perekonomian dan intermediasi perbankan. 
halaman ini sengaja dikosongkan 